Available online at https://jurnal.stmikroyal.ac.id/index.php/jurdimas

\title{
PENINGKATAN KUALITAS HIDUP DI MASA PANDEMI COVID-19 DENGAN PENERAPAN POLA HIDUP SEHAT
}

\author{
Tania Intan $^{1 *}$, Ferli Hasanah ${ }^{1}$, Sri Rijati Wardiani ${ }^{1}$, Vincentia Tri Handayani ${ }^{1}$ \\ ${ }^{1}$ Fakultas Ilmu Budaya, Universitas Padjadjaran \\ email: *tania.intan@unpad.ac.id
}

\begin{abstract}
Good living behavior is a community habit that upholds health aspects, such as managing cleanliness and environmental health, maintaining physical and psychological fitness, and providing adequate nutritional intake to achieve good health standards. Community Service Activities regarding the culture of healthy living during this pandemic were carried out by a teaching team from the Faculty of Humanities Sciences, Padjadjaran University. The activity method used is education with techniques of extension, consultation, and diffusion of knowledge which are all held virtually. To obtain comprehensive data, the implementation team distributed a questionnaire about the culture of healthy living to the primary target public, namely students of the Faculty, and the secondary target public, namely student families. Activities were carried out in July 2020 in three stages, namely the preparation, implementation, and evaluation stages. The results of the activity showed that PPM activities regarding healthy cultural behavior to the public of students and their families were well organized and following the protocol for preventing the transmission of Covid-19. Also, it is known that the biggest impact of a pandemic is economic.
\end{abstract}

Keywords: covid-19; culture of healthy living; pandemic; virtual socialization

\begin{abstract}
Abstrak: Perilaku hidup sehat adalah kebiasaan masyarakat yang menjunjung tinggi aspekaspek kesehatan, seperti pengelolaan kebersihan dan kesehatan lingkungan, menjaga kebugaran fisik dan psikis, serta pemberian asupan nutrisi yang cukup sehingga tercapai standar kesehatan yang baik. Kegiatan Pengabdian Pada Masyarakat tentang budaya hidup sehat di masa pandemi ini dilakukan oleh tim pengajar dari Fakultas Ilmu Budaya Universitas Padjadjaran. Metode kegiatan yang digunakan adalah pendidikan dengan teknik penyuluhan, konsultasi, dan difusi ilmu pengetahuan yang seluruhnya diselenggarakan secara virtual. Untuk mendapatkan data yang komprehensif, tim pelaksana mendistribusikan angket mengenai budaya hidup sehat pada publik sasaran primer, yaitu mahasiswa, dan publik sasaran sekunder, yaitu keluarga mahasiswa. Kegiatan dilakukan pada bulan Juli 2020 dalam tiga tahap, yaitu tahap persiapan, pelaksanaan, dan evaluasi. Hasil kegiatan menunjukkan bahwa kegiatan PPM mengenai perilaku budaya sehat kepada publik mahasiswa dan keluarganya telah terselenggara dengan baik dan sesuai dengan protokol pencegahan penularan Covid-19. Selain itu diketahui bahwa dampak terbesar dari pandemi adalah ekonomi.
\end{abstract}

Kata kunci: budaya hidup sehat; Covid-19; pandemic; sosialisasi virtual 
Available online at https://jurnal.stmikroyal.ac.id/index.php/jurdimas

\section{PENDAHULUAN}

Pandemi Covid-19 telah me ngubah berbagai aspek kehidupan manusia di seluruh dunia. Masih tingginya angka kematian dan terus meningkatnya jumlah kasus baru, yaitu sekitar 3 juta hingga bulan Mei 2020 (Salsabila, \& Meiyanto, 2020), merupakan realitas yang tidak dapat disangkal. Situasi darurat kesehatan ini pun menuntut diberlakukannya Normalitas Baru, sebagai bentuk penyesuaian dalam kegiatan sehari-hari. Sejumlah besar himbauan secara lisan maupun tulisan juga telah disampaikan kepada masyarakat agar penularan dan perkembangbiakan virus tidak terus terjadi. Berbagai kebijakan seperti work from home, physical distancing, lockdown, hingga penerapan gaya hidup sehat terus digalakkan di semua tingkatan sosial.

Menghadapi kondisi ini, para akademisi pun melakukan berbagai penelitian dan langkah strategispartisipasif yang bertujuan untuk mengurai permasalahan akibat pandemik Covid-19. Kajian terhadap pembelajaran di masa pandemi misalnya dilakukan oleh( Herliandry, 2020), yang menyepakati bahwa pembelajaran daring merupakan solusi efektif untuk tetap mengaktifkan kelas meskipun hampir seluruh sekolah telah ditutup. Dari perspektif psikologis, (Buana, 2020) menelaah perilaku masyarakat Indonesia dalam meng-hadapi pandemi. Penelitian itu juga memaparkan kiat-kiat untuk menjaga kesejahteraan jiwa. Hasil kajian menunjukkan bahwa perilaku masyarakat yang tidak mematuhi protokol kesehatan yang ditetapkan pemerintah didasari oleh bias kognitif.

Segala upaya perlu dikerahkan mulai dari hulu ke hilir, dari sektor ekonomi hingga kesehatan. Perilaku hidup sehat sejatinya merupakan budaya yang harus terus diupayakan hingga menjadi kebiasaan. Perilaku ini juga selayaknya terus disosialisasikan baik dalam lingkup keluarga maupun lingkungan sekitar. (Guang, 2002) menyatakan bahwa $80 \%$ dari penyakit kronis yang menyerang manusia disebabkan oleh gaya hidup yang salah, dan $20 \%$ disebabkan oleh faktor lain seperti keturunan dan penularan.

Perilaku hidup sehat adalah kebiasaan masyarakat yang men-junjung tinggi aspek-aspek kesehatan, seperti pengelolaan kebersihan dan kesehatan lingkungan, menjaga kebugaran fisik dan psikis, serta pemberian asupan nutrisi yang cukup sehingga tercapai standar kesehatan yang baik. Jika kebiasaan rutin dikelola dengan baik sesuai dengan kaidah-kaidah yang benar, maka akan terbentuk kebiasaan yang baik (Suharjana, 2012), berupa pola hidup sehat. Sebaliknya menurut (Zahra, \& Irawati, 2016), kesibukan, polusi, dan pola hidup yang tidak diatur dengan baik mengharuskan masyarakat melakukan langkah-langkah ekstra untuk mempertahankan hidupnya.

Gaya atau pola hidup sehat juga dapat diinterpretasikan sebagai upaya dari setiap orang yang ingin selalu sehat dengan melakukan kebiasaan-kebiasaan yang mempengaruhi kesehatannya. Untuk mencapai pola hidup sehat yang optimal, setiap individu harus melakukan langkah-langkah seperti menjaga kebersihan diri, makan dan minum yang sehat, keseimbangan kegiatan yang cukup, berolahraga secara teratur, dan melakukan pencegahan terhadap penyakit (Susanti, \& Kholisoh, 2018). 
Available online at https://jurnal.stmikroyal.ac.id/index.php/jurdimas

Tabel 1 Pola Hidup Sehat dan Tidak Sehat

\begin{tabular}{cll}
\hline No & \multicolumn{1}{c}{ Sehat } & \multicolumn{1}{c}{ Tidak Sehat } \\
\hline 1 & $\begin{array}{l}\text { Mengonsumsi makanan dengan gizi } \\
\text { seimbang. }\end{array}$ & $\begin{array}{l}\text { Mengonsumsi makanan apa saja yang } \\
\text { penting enak dan cepat saji. }\end{array}$ \\
\hline 2 & $\begin{array}{l}\text { Mengonsumsi makanan berserat tinggi, } \\
\text { sayuran, dan buah segar setiap hari. }\end{array}$ & $\begin{array}{l}\text { Jarang mengonsumsi makanan berserat } \\
\text { tinggi, sayuran, dan buah segar setiap hari } \\
\text { (hanya kalau ingin dan ingat). }\end{array}$ \\
\hline 3 & $\begin{array}{l}\text { Menghindari makanan yang } \\
\text { mengandung banyak lemak, gula, atau } \\
\text { garam. }\end{array}$ & $\begin{array}{l}\text { Suka mengonsumsi makanan yang } \\
\text { mengandung banyak lemak, gula, atau } \\
\text { garam. }\end{array}$ \\
\hline 4 & $\begin{array}{l}\text { Mengonsumsi susu atau produk dari } \\
\text { susu setiap hari. }\end{array}$ & $\begin{array}{l}\text { Kadang-kadang kalau ingin saja } \\
\text { mengonsumsi susu atau produk dari susu. }\end{array}$ \\
\hline 5 & Tenang dan selalu berpikir positif. & Pikiran mudah stress dan sering pusing. \\
\hline 6 & Berat badan dalam batas normal. & $\begin{array}{l}\text { Berat badan lebih atau kurang dari berat } \\
\text { badan ideal. }\end{array}$ \\
\hline 7 & Olahraga teratur. & $\begin{array}{l}\text { Kadang-kadang jika mau, atau sama sekali } \\
\text { tidak berolahraga. }\end{array}$ \\
\hline 8 & Cukup istirahat. & Banyak kerja lembur dan keluar malam. \\
\hline 9 & Minum air putih 1,5 - 2 liter per hari. & $\begin{array}{l}\text { Lebih suka minum kopi atau teh daripada air } \\
\text { putih. }\end{array}$ \\
\hline 10 & Tidak merokok. & Banyak merokok. \\
\hline
\end{tabular}

Pada tabel 1 merupakan rumusan mengenai pola hidup sehat dan tidak sehat (Kemendiknas, 2010), dalam konteks pandemi Covid-19. Perilaku hidup sehat tersebut diwujudkan dalam tindakan sanitasi yang lebih spesifik, seperti mencuci tangan dengan sabun dan air mengalir, menggunakan hand sanitizer dan masker.

\section{METODE}

Metode yang digunakan untuk kegiatan PPM ini adalah pendidikan dengan teknik penyuluhan/sosialisasi secara virtual, yang bertujuan meningkatkan pemahaman dan kesadaran peserta. Selain pendidikan, teknik lain yang digunakan adalah konsultasi. Dengan demikian, melalui pendidikan dan konsultasi ini, permasalahan dapat diatasi berkat sinergi di antara masyarakat dan perguruan tinggi. Kegiatan ini pun merupakan realisasi dari upaya difusi ilmu pengetahuan dan hasil penelitian kepada masyarakat secara langsung.

Kegiatan PPM terbagi dalam tiga tahap, yaitu: survey/pemetaan, pelaksanaan, dan evaluasi. Yang menjadi publik sasaran primer adalah sampel mahasiswa berjumlah 17 orang dan publik sasaran sekunder adalah keluarga mereka.

\section{PEMBAHASAN}

Bagian pembahasan akan terdiri dari tiga bagian yaitu: tahap persiapan, pelaksanaan kegiatan, serta evaluasi dan keberlanjutan kegiatan.

\section{Tahap Persiapan}

Tahap pertama dilakukan dengan melaksanakan survey dan penyebaran angket tentang pola hidup sehat yang didistribusikan pada 80 orang mahasiswa melalui kontak daring pada tanggal 3 Juli 2020. Sebanyak 56 orang mengisi angket tersebut, dan 17 orang di antaranya 
Available online at https://jurnal.stmikroyal.ac.id/index.php/jurdimas

dipilih sebagai peserta kegiatan PPM. Pemilihan peserta didasari oleh data yang didapatkan pada tahap survey melalui pengisian angket. Sasaran peserta terutama adalah mahasiswa yang tinggal di daerah periferal dan pedesaan, serta berstatus sebagai penerima beasiswa BIDIK MISI.

Setelah menetapkan peserta, tim kemudian melaksanakan rapat pada tanggal 13 Juli 2020 untuk merancang kegiatan selanjutnya, yang terdiri dari penentuan waktu, pembagian tugas, penyiapan materi sosialisasi, penyiapan bantuan pulsa dan sertifikat, serta hal-hal teknis lainnya.

Dari hasil rekapitulasi dan analisis terhadap angket, diperoleh informasi sebagai berikut ini. Seluruh responden berjumlah 56 orang, terdiri dari 26 mahasiswa dari semester 2 dan 30 mahasiswa dari semester 4. Untuk selanjutnya data disampaikan dalam bentuk presentase.

\section{Tabel 2 Hasil Angket pada Responden}

\begin{tabular}{cl}
\hline Persentase & \multicolumn{1}{c}{ Kondisi Responden } \\
\hline $85 \%$ & Tinggal dengan orang tua \\
\hline $83 \%$ & Memperbarui informasi tentang kasus Covid-19 dari berbagai media \\
\hline $78 \%$ & Kuatir, cemas, takut, sedih mengikuti berita tentang Covid-19 \\
\hline $96 \%$ & $\begin{array}{l}\text { Ada perilaku yang berubah sebelum dan saat sedang berkembang penyebaran } \\
\text { Covid-19 (sering cuci tangan, menggunakan hand sanitizer, memakai masker) }\end{array}$ \\
\hline $51 \%$ & Menghindari penularan Covid-19 dengan cara tinggal di rumah \\
\hline $63 \%$ & Tidak ada tetangga atau kerabat yang tertular Covid-19 \\
\hline $75 \%$ & $\begin{array}{l}\text { Ada tindakan pencegahan yang dilakukan (penyemprotan disinfektan, jam } \\
\text { malam, pembatasan pengunjung, penyebaran informasi) }\end{array}$ \\
\hline $63 \%$ & Tidak menerima bantuan apapun dari pemerintah setempat \\
\hline $66 \%$ & Terdampak secara ekonomi (pendapatan menurun, biaya listrik meningkat) \\
\hline $71 \%$ & Berharap pandemi segera berakhir dan kehidupan normal kembali \\
\hline $50 \%$ & Tidak selalu memantau jumlah kasus baru Covid-19 karena jenuh \\
\hline $100 \%$ & Selalu menggunakan masker ketika keluar rumah \\
\hline $96 \%$ & Selalu menghindari kerumunan \\
\hline $96 \%$ & Selalu menghindari bersentuhan dengan orang lain \\
\hline $96 \%$ & Selalu mencuci tangan dengan sabun dan air mengalir ketika masuk rumah \\
\hline $98 \%$ & Menyediakan hand sanitizer di rumah \\
\hline $98 \%$ & $\begin{array}{l}\text { Selalu saling mengingatkan di antara anggota keluarga untuk mematuhi } \\
\text { protokol kesehatan }\end{array}$ \\
\hline $60 \%$ & Mengonsumsi suplemen kesehatan \\
\hline $57 \%$ & $\begin{array}{l}\text { Selalu mengonsumsi jamu dan minuman herbal untuk memperkuat daya tahan } \\
\text { tubuh }\end{array}$ \\
\hline $82 \%$ & Selalu menghindari bersalaman dengan kerabat dan teman \\
\hline $96 \%$ & Mengurangi frekuensi bepergian \\
\hline $92 \%$ & Pola konsumsi rumah tangga berubah drastis \\
\hline $63 \%$ & Tidak mengadakan dan tidak menghadiri acara perayaan \\
\hline & Tidak melakukan olahraga secara rutin \\
\hline & Tetap berusaha berpikir positif dan optimis \\
\hline
\end{tabular}


Available online at https://jurnal.stmikroyal.ac.id/index.php/jurdimas

Rekapitulasi data dari angket ini menunjukkan bahwa kondisi keluarga dan lingkungan sekitar responden di masa pandemi. Tingkat kesadaran peserta untuk melakukan pola hidup sehat dapat dinilai cukup baik, namun tidak terlalu menggembirakan karena terungkap inkonsistensi berupa perilaku tidak disiplin. Kegiatan PPM selanjutnya diharapkan dapat mengubah paradigma yang tidak tepat sehingga meningkatkan nilai kesadaran tersebut menjadi lebih baik. Setelah melakukan persiapan teknis dan merancang materi, tim pelaksana pun mengundang peserta untuk hadir pada pertemuan virtual. Selain peserta, kegiatan ini juga melibatkan dosen perwakilan fakultas.

\section{Pelaksanaan Kegiatan}

Kegiatan sosialisasi diselenggarakan pada tanggal 15 Juli 2020 yang diikuti 17 peserta mahasiswa, 6 dosen perwakilan fakultas, dan 3 dosen dari tim pelaksana PPM. Pertemuan dilakukan pada ruang maya dari pukul 13-15 dengan menggunakan platform Google Meet. Kegiatan dilakukan secara daring/ online sehingga secara teknis, banyak dilakukan penyesuaian. Acara dibuka oleh Ketua Program Studi Sastra Perancis, Dr. Sri Rijati Wardiani, M. Hum. Selanjutnya dilakukan pemberian materi selama 30 menit dan tanya jawab selama 20 menit.

Materi yang disampaikan pada peserta kegiatan terdiri dari infografis dan foto-foto. Pertanyaan peserta berkaitan dengan permasalahan ekonomi karena dampak pandemi, protokol kesehatan dalam menggunakan masker, olahraga di masa pandemi, pengelolaan gizi, dan lain-lain. Setelah diskusi dan tanya jawab, acara pun ditutup dan dilakukan sesi foto bersama sebagai dokumentasi.

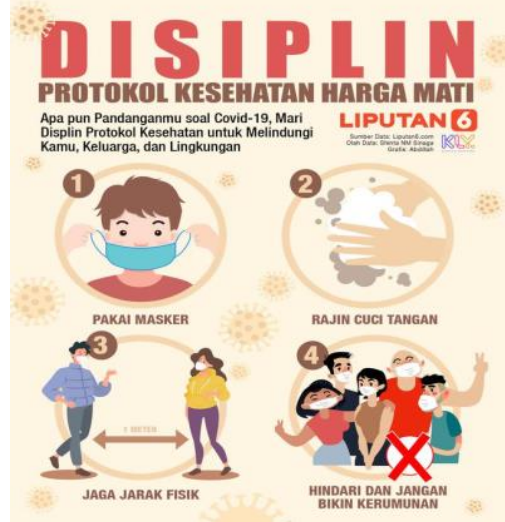

Gambar 1 Contoh Infografis tentang Tips Hidup Sehat

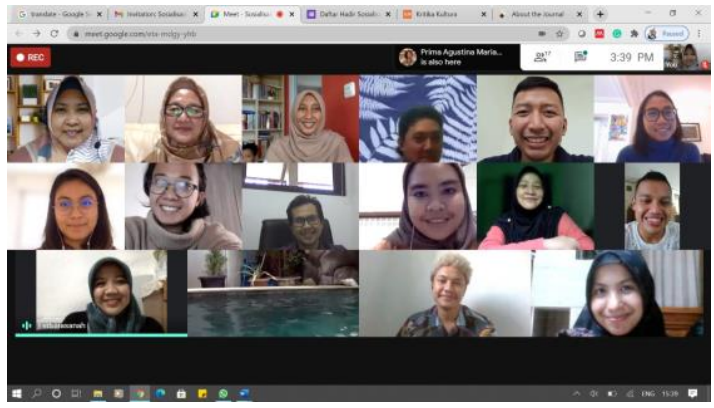

Gambar 2 Para Peserta Kegiatan PPM

\section{Evaluasi dan Keberlanjutan Kegiatan PPM}

Sebagai evaluasi atas kegiatan PPM, dapat dinyatakan bahwa seluruh rangkaian acara terselenggara dengan baik. Hal tersebut ditunjukkan oleh kehadiran dan partisipasi aktif seluruh peserta yang diundang serta antusiasme yang tinggi ketika berdiskusi. Selain itu, peserta mendapatkan kesadaran dan pemahaman baru tentang arti penting pola hidup sehat terutama selama masa pandemi.

Kendala yang ditemui dalam pelaksanaan kegiatan ini adalah sinyal internet yang lemah sehingga mengakibatkan tampilan visual dan audio saat presentasi dari narasumber mengalami gangguan. Selain itu, keterbatasan waktu pun menyebabkan waktu untuk berdiskusi tidak memadai. 
Available online at https://jurnal.stmikroyal.ac.id/index.php/jurdimas

Sebagai apresiasi atas partisipasi peserta dalam kegiatan PPM, tim pelaksana memberikan hadiah pulsa dan sertifikat elektronik untuk seluruh peserta. Tim pelaksana berharap agar kegiatan yang telah terselenggara dapat memberikan manfaat dan dapat disosialisasikan lebih jauh oleh peserta pada keluarga dan orang-orang di lingkungannya. Sebagai bentuk keberlanjutan dari kegiatan PPM ini, tim pelaksana telah merancang kegiatan baru yang ditujukan pada publik sasaran yang lebih luas. Selain itu, tim mengupayakan adanya pemantauan berkala dan tersedianya ruang konsultasi bagi peserta yang mengalami permasalahan akibat pandemi.

\section{SIMPULAN}

Sosialisasi secara virtual mengenai perilaku budaya sehat kepada publik mahasiswa dan keluarganya yang tinggal di wilayah rural ini telah terselenggara dengan baik dan sesuai dengan protokol pencegahan penularan Covid-19. Kesadaran dan pendisiplinan untuk mempraktikkan budaya hidup sehat harus terus dibangun dan dijalankan. Kebiasaan hidup yang baik perlu dikelola secara rutin hingga menjadi gaya hidup yang menetap pada setiap individu. Konsistensi adalah hal terpenting untuk menjaga keberlangsungan hidup dan produktivitas bersama di masa pandemi ini.

\section{DAFTAR PUSTAKA}

Buana, D. R. (2020). Analisis Perilaku Masyarakat Indonesia dalam Menghadapi Pandemi Virus
Corona (Covid-19) dan Kiat Menjaga Kese-jahteraan Jiwa. Salam: Jurnal Sosial Dan BuDaya Syar'i, 7(3), 217-226.

Guang, H. Z. (2002). "Gaya Hidup Usia Pertengahan dan Usia Lanjut serta Pengaruhnya terhadap Kesehatan."

Herliandry, L. D. dkk. (2020). Pembelajaran pada Masa Pandemi Covid-19. Jurnal Teknologi Pendidikan, 22(1), 65-70.

Kemendiknas. (2010). Pengembangan Pendidikan Budaya dan Karakter Bangsa. Bahan Pelatihan Penguatan Metodologi Pembelajaran Berdasarkan Nilainilai Budaya untuk Membentuk Daya Saing dan Karakter Bangsa. Jakarta: Kemendiknas.

Salsabila, I.A. \& Meiyanto, E. (2020). Menjaga Hidup Bersih dan Sehat Pasca Pandemi. Retrieved July 10, 2020, from farmasi.ugm.ac.id website:

http://farmasi.ugm.ac.id/id/menjag a-hidup-bersih-dan-sehat-pascapandemi-covid-19

Suharjana. (2012). Kebiasaan Berperilaku Hidup Sehat dan Nilai-nilai Pendidikan Karakter. Jurnal Pendidikan Karakter, 2(2), 189-201.

Susanti, E. \& Kholisoh, N. (2018). Konstruksi Makna Kualitas Hidup Sehat (Studi Fenomenologi pada Anggota Komunitas Herbalife Klub Sehat Ersanddi Jakarta). Jurnal Lugas, 2(1), 1-12.

Zahra, G.F; Irawati, D. (2016). Pengaruh Gaya Hidup Sehat, Harga, dan Kelompok Referensi terhadap Keputusan Pembelian Susu Anlene di Kebumen. Jurnal Manajemen Dan Bisnis, 12(1), 1-11. 